This is an electronic reprint of the original article. This reprint may differ from the original in pagination and typographic detail.

Author(s): Ojala, Arto; Kontinen, Tanja

Title: $\quad$ Distance Factors in the Foreign Market Entry of Software SMEs

Year: $\quad 2010$

Version:

Please cite the original version:

Ojala, A., \& Kontinen, T. (2010). Distance Factors in the Foreign Market Entry of Software SMEs. In Software Business (pp. 49-62). Springer.

https://doi.org/10.1007/978-3-642-13633-7_5

All material supplied via JYX is protected by copyright and other intellectual property rights, and duplication or sale of all or part of any of the repository collections is not permitted, except that material may be duplicated by you for your research use or educational purposes in electronic or print form. You must obtain permission for any other use. Electronic or print copies may not be offered, whether for sale or otherwise to anyone who is not an authorised user. 


\title{
Distance factors in the foreign market entry of software SMEs
}

\author{
Arto Ojala and Tanja Kontinen \\ School of Business and Economics \\ University of Jyväskylä, Finland
}

\begin{abstract}
Recent studies have indicated that the internationalization process of software SMEs is somewhat independent on the effect of psychic or geographic distance. However, these studies have analyzed the general pattern of entries where software SMEs not commonly follow a step-wise entry route from nearby countries to distant ones. Thus, it remains unknown what the effect of psychic and geographical distance is when these firms enter a distant foreign market. The findings in this case study reveal that psychic and geographic distance inhibited the foreign market entry of software SMEs. However, the distant foreign market entry of these firms was facilitated by distance-bridging and distance-compressing factors enabling foreign business operations despite the significant distance between the home and target country.
\end{abstract}

Keywords: Psychic distance, geographic distance, SMEs, software firms

\section{Introduction}

The impact of geographical and psychic distance on firm internationalization has a long tradition in international business and marketing literature. Already in 1950s, Beckerman [1] proposed that, if transportation costs are equal, entrepreneurs favor psychically close markets. The concept became well known in the 1970s after the studies by Johanson and Wiedersheim-Paul [2] and Johanson and Vahlne [3] known as the Uppsala model. In their study, Johanson and Wiedersheim-Paul [2] define psychic distance as a sum of factors that constrict the flow of information between the firm and the market. Thus, in the model, large psychic distance between countries inhibits the foreign market entry of the firm. In addition to psychic distance, large geographical distance has been indicated having the same effect [4], [5].

In the Uppsala model, firms are expected to enter first into nearby markets which share a similar language, culture, political system, level of education, level of industrial development etc. Thereafter, when a firm's knowledge to operate internationally increases, it gradually starts to develop activities in psychically more distant countries [3]. However, empirical studies related to internationalization of software small and medium-sized enterprises (SMEs) have argued that these SMEs do not follow any particular stages in their internationalization process (see e.g., [6], [7], [8]). For instance, Bell [6, 64-65] announces that "...the data also revealed the some 30-50 per cent of firms had initiated exports with sales to countries which could not 
be considered either psychologically or geographically proximate" and “...'establishment chain' theories proposed by the Uppsala School authors do not adequately reflect the understanding factors which influence the internationalization patterns of small software firms" [6, 71]. Based on these studies, it seems to be evident that rapidly internationalizing software SMEs do not generally follow the gradual internationalization process from psychically or geographically nearby markets to more distant ones as proposed in the Uppsala model. This conclusion has evoked discussion that psychic and geographical distance have a less important role in the foreign market entry of firms operating in knowledge-intensive sectors [9]. However, the focus of these studies has been on networks [7], entry mode and market selection [8], and internationalization process [6], but the actual effect of psychic or geographic distance on the foreign market entry has been ignored. That is, earlier studies have investigated the general pattern of internationalization but we do not know whether psychic and geographical distance impact on the foreign market entry when firms enter a certain foreign country. In this article, we argue that although these distance factors do not impact on general internationalization process, they still have a remarkable role in the foreign market entry. In addition, we show how these firms are able to tackle the effect of psychic and geographical distance by using proper market entry strategies.

Based on the above discussion, the following three questions are of particular interest in this study: 1) What are the distance-creating factors in the distant foreign market entry encountered by software SMEs? 2) What are the distance-bridging factors that software SMEs use to facilitate their distant foreign market entry? 3) What are the distance-compressing factors facilitating the distant foreign market entry of software SMEs? By investigating to these questions, we use the theoretical framework of Child et al. [10] that divide the components of psychic distance into distance-creating, distance-bridging, and distance-compressing factors.

\section{Literature Review}

\subsection{Distance-creating factors}

In literature, psychic distance, cultural distance, and geographical distance have been commonly cited as distance-creating factors. In their model, Johanson and Wiedersheim-Paul [2, 308] define psychic distance as “...factors preventing or disturbing the flow of information between firm and market". Thus, the model indicates that psychic distance consists of factors creating distances, such as language, culture, political system, level of education, and level of industrial development. Because of these distance-creating factors, firms are expected to enter first nearby markets where the business environment is similar to the home market. Thereafter, when a firm's knowledge to operate internationally increases, it gradually starts to develop activities in psychically more distant countries. The study of Nordström and Vahlne $[11,42]$ defines psychic distance as "factors preventing or disturbing firms' 
learning about and understanding of a foreign environment". This definition refers to the fact that firms have to learn about the environment of the target country and understand the local culture. In their framework, Child et al. [10, 49] argue that "Distance-creating factors are those responsible for dissimilarity in business environments between the home country and the host countries for investment". They found that culture (including language) was the most important element that created distances and difficulties in the foreign market entry and operations of Hong-Kong family firms.

Cultural distance between countries is also seen as a factor creating difficulties in the foreign market entry. Sousa and Bradley [12, 63] define the difference between cultural and psychic distance as follows: "Cultural distance reflects a difference in cultural values among countries" and "Psychic distance is based on the individual's perception". Cultural differences between countries have commonly been measured by using Hofstede's [13] cultural dimensions and the composite index of Kogut and Singh [14]. These studies (see [15] for further review) have been motivated by the assumption that cultural differences between countries inhibit market entry to culturally distant countries. However, in many cases, the results have been conflicting and there has been a growing amount of criticism toward the usage of Hofstede's [13] cultural dimensions as single determinant for the foreign market entry decision (see e.g., [4], [15]). For instance, the study of Dow and Karunaratna [4] proposes that cultural distance is only one dimension of the larger concept of psychic distance.

The third commonly cited distance-creating factor is geographical distance. Srivastava and Green [5] found that geographical distance has the most significant impact on the trade intensity between countries. This is also line with findings of Dow and Karunaratna [4] indicating that geographic distance is the most influential inhibitor of international trade. In addition, Leamer and Storper [16] indicate that geographical distance is still a valid inhibitor despite improvements of transportation systems and communication technologies. Ojala and Tyrväinen [17], [18] suggest that geographic distance even impacts on the initial market selection of software SMEs.

Altogether, the current literature indicates that psychic and geographical distances are major distance-creating factors whereas the role of cultural distance is more complex and the results have been contradicting. In addition, psychic distance is multidimensional including several factors (see e.g., [4]) and its impact depends on entrepreneur's perceptions about differences between countries [19], [12]. Thus, this study takes a wider perspective to distance-creating factors than the study of Child et al. [10]. In addition, similarly to Sousa and Bradley [12], distance-creating factors are conceptualized here as individual-level perceptions of firm's decision makers. Thus, this study defines distance-creating factors as a sum of factors, based on the perceptions of an entrepreneur or a manager, inhibiting or restricting firm's entry into a new foreign market.

\subsection{Distance-bridging factors}

In their study, Child et al. [10, 50] define distance-bridging factors as "...factors, which are open to the initiatives of firms themselves". These factors consist of strategic and operational activities where strategic decisions are related to locations 
choice for foreign markets and operational activities are related to the managerial operations in the target country. In line, Nordström and Vahlne [11, 46] indicate the role of distance-bridging factors by arguing that "... distance can be bridged by factors such as knowledge dissemination...or trial and error processes". Thus, distancebridging factors are largely under the control of an individual firm or an entrepreneur. This is well present in the international entrepreneurship literature revealing the important role of entrepreneurial activities in the foreign market entry. Scholars [20], [21], [22] have indentified positive relationships between managers' opportunity seeking behavior in the early internationalization. In addition, managers' earlier experiences can facilitate the market entry [20], [21], [23]. Coviello and Martin [24] found that psychic distance can be overcome by recruiting experienced personnel with knowledge of the distant country. Furthermore, the distance-bridging role of network relationships for early internationalization is acknowledged in several studies [25], [24], [26]. For instance, Coviello and Martin [24] argue that the usage of network relationships significantly reduced perceived psychic distance.

Summarizing, there seems to be several distance-bridging factors which facilitate and enable a firm's entry to a distant market despite distance-creating factors. Thus, distance-bridging factors are defined here as any action taken by an entrepreneur or a manager to decrease the impact of distance-creating factors in the foreign market entry.

\subsection{Distance-compressing factors}

According to the definition by Child et al. [10], distance-compressing factors refer to macroeconomic changes, such as social movements, institutional changes, globalization, and technological development. For instance, Oviatt and McDougall [22], [23] indicate the distance-compressing role of the worldwide development of information and communications technologies that facilitate the foreign market entry of new ventures. In addition, some studies reveal the distance-compressing effect of increasing international traveling and mass-media. This has been labeled as global cultures where people share similar values and behavior regardless of their original cultural background or geographic location [27], [28]. This has made foreign markets easier for firms to enter [10] and some products less culturally sensitive. Other examples of distance-compressing factors are the free trade areas and the trade agreements between nations such as the General Agreement on Tariffs and Trade (GATT), European Union (EU), and the North American Free Trade Agreement (NAFTA). In addition, the establishment of organizations like World Trade Organization (WTO) facilitates business between countries. The aim of these agreements and areas is to decrease trade barriers between countries and, consequently, facilitate the foreign market entries of SMEs (see e.g., [29], [30]). All together, these activities or macroeconomic changes are largely out of the individual entrepreneur's or manager's control. Thus, distance-compressing factors are defined here as a sum of factors facilitating firm's foreign market entry that are not under a control of an entrepreneur or a manager. 


\section{Research Method}

This study employs a qualitative case study method [31] including eight Finnish software firms entering the Japanese market. The case study approach was selected because of the need to analyze the firm level and the individual level behavior in detail to come to an understanding about the behavior of the firms in the foreign market entry process. This enables explaining the significance and cause-and-effect relationships of the phenomena under investigation [31]. In addition, Eisenhardt [32] suggests that the multiple case study method allows studying patterns that are common to the cases and theory under investigation.

Finnish software SMEs operating in the Japanese market were selected as the target group of this study. The selection of the host and target countries is based on several methodological and theoretical reasoning. Firstly, Finland and Japan are culturally and geographically very distant from each others. This helps to find out potential impact of psychic or geographical distance in the market entry that would not be observable if two countries selected are very close to each others. Secondly, both countries have their own languages; Finnish is spoken only in Finland and Japanese in Japan. In addition, both languages differ greatly from other major languages such as English that is commonly used in international business. Thirdly, both countries are culturally very homogenous, and, accordingly, there are no large cultural differences within the countries. This helps us to overcome the criticism of Shenkar [33] related to 'the assumption of spatial homogeneity'.

All eight case firms selected for this study fulfilled the definition by the Finnish government and European Union [34] for SMEs having fewer than 250 employees at the time of their market entry to the Japanese market. The case firms were from software industry, and even if it might be seen as a limitation, several studies analyzing internationalization of knowledge-intensive firms have used software industry as a target group in their studies (see e.g., [6], [25]). Despite the fact that software industry differs somewhat from other industries due to the intangible nature of its products, etc. it still shares common characteristics with other knowledgeintensive industries [35] and the service sector [36].

The interviews for this study were conducted in the headquarters of the firms in Finland and in their units in Japan covering altogether 16 interviews from the eight firms. The main criterion for interviewed persons was that they were actively involved in their firm's entry process to the Japanese market. By selecting the most knowledgeable persons, and by using two informants from each firm, we aimed to get the most relevant knowledge, and to counteract the biases of individual opinions [37]. In addition, having two interviews from each case firm also made it possible to ask more detailed questions of the second interviewee, following on from the first interview. Working in this way improved the validity of the data collected. The interviews were rather conversational and focused mainly on open-ended questions related to the firms' market entry into the Japanese market and its operations there. All these questions were developed according to the guidelines issued by Yin [31], with the aim of making the questions as non-leading as possible. This encouraged the interviewees to give authentic answers to the interview questions. Because the 
interviews focused on the managers' past experiences, we followed the guidelines for retrospective studies issued by Miller et al. [38] and by Huber and Power [37].

Each interview took approximately 60-90 minutes and was digitally recorded, carefully listened to, and transcribed verbatim with the help of a word processor. A second listening took place to ensure the correspondence between the recorded and the transcribed data. Thereafter, the complete case reports were sent back to the persons interviewed to ensure the validity and the authenticity of the collected data. Whenever the interviewees found some inaccuracies in the text, these were corrected based on their comments. In addition, e-mail communication was used to collect further information and to clarify any inconsistent issues. To improve the validity of the study we collected and analyzed many types of secondary information (such as websites and annual reports). By comparing the interview data with other documents from the case firms, we carried out triangulation on the information [39], [40]. This also provided a more complete picture of the case firms under study [39].

In the data analysis, we arrived at a detailed case history of each firm based on the interviews and written documents in line with Pettigrew [41], who suggests that organizing incoherent aspects in chronological order is an important step in understanding the causal links between events. Thereafter, on the basis of the interviews, we identified the unique patterns of each case and categorized the patterns observed under the sub-topics derived from the three research questions we had set for the study. These sub-topics included distance-creating factors, distance-bridging factors, and distance-compressing factors. In addition, analytical tools were applied within and across the cases as proposed by Miles and Huberman [40].

\section{Research findings}

This section presents the empirical findings by categorizing them into distancecreating, distance-bridging, and distance-compressing factors. The average number of employees in the case firms at the time of the interviews was 127. All the case firms were established between 1990 and 2000, except from Firm C that was established already in 1966. The firms had operated in the Japanese market from three to seven years. Table 1 summarizes the key information of the case firms and demonstrates their foreign direct investments before the market entry to Japan. Entry modes used by each case firm in Japan are presented in a chronological order. 
Table 1. Key information on the case firms

\begin{tabular}{|c|c|c|c|c|}
\hline & $\begin{array}{l}\text { Number of } \\
\text { employees }\end{array}$ & $\begin{array}{l}\text { Year of } \\
\text { establishment }\end{array}$ & $\begin{array}{l}\text { Foreign direct business } \\
\text { operations }\end{array}$ & Entry modes in Japan \\
\hline Firm A & 30 & 1998 & $\begin{array}{l}\text { USA } 1998 \\
\text { Hungary } 2000 \\
\text { Japan } 2002\end{array}$ & Representative 2002 \\
\hline Firm B & 90 & 1992 & $\begin{array}{l}\text { USA } 2000 \\
\text { Japan } 2002\end{array}$ & Representative office 2002 \\
\hline Firm C & 300 & 1966 & $\begin{array}{l}\text { Sweden } 1995 \\
\text { USA } 1999 \\
\text { Malaysia } 1999 \\
\text { Germany } 1999 \\
\text { UK } 1999 \\
\text { Japan } 2000\end{array}$ & $\begin{array}{l}\text { Distributors } 1999 \\
\text { Representative office } 2000 \\
\text { Subsidiary } 2001\end{array}$ \\
\hline Firm D & 240 & 1990 & $\begin{array}{l}\text { USA } 1998 \\
\text { Japan } 1999\end{array}$ & $\begin{array}{l}\text { Representative office } 1999 \\
\text { Subsidiary } 2000\end{array}$ \\
\hline Firm E & 100 & 1995 & $\begin{array}{l}\text { USA } 1998 \\
\text { Japan } 2000\end{array}$ & $\begin{array}{l}\text { Direct sales } 1999 \\
\text { Subsidiary } 2000\end{array}$ \\
\hline Firm F & 210 & 1991 & $\begin{array}{l}\text { Sweden } 1999 \\
\text { Hong Kong } 2000 \\
\text { Japan } 2001\end{array}$ & $\begin{array}{l}\text { Distributor } 1997 \\
\text { Joint Venture } 2001 \\
\text { Subsidiary } 2005\end{array}$ \\
\hline Firm G & 12 & 1998 & Japan 1999 & Joint venture 1999 \\
\hline Firm $\mathrm{H}$ & 35 & 2000 & $\begin{array}{l}\text { UK } 2000 \\
\text { Japan } 2003\end{array}$ & Corporate 2003 \\
\hline
\end{tabular}

\subsection{Distance-creating factors encountered by the case firms}

All the case firms experienced Japan as a difficult country to enter. The main factors that can be conceptualized as distance-creating factors in the market entry were related to differences in language, business culture, and geographic distance between Finland and Japan.

Language was seen as a distance-creating factor in all firms. Although English was used as an official language in all case firms, the low English proficiency of Japanese customers and partners created problems. The language related problems consisted of networking with potential customers, misunderstandings with customers, and localization of products. For instance, Firm $\mathrm{H}$ was searching for a Japanese partner in the Internet. However, language difficulties created remarkable problems. One informant from Firm $\mathrm{H}$ explained this as follows:

"Finding a partner in Japan via Internet was difficult, because they have their websites only in Japanese and only few firms have English versions. Of course large 
multinational firms have their websites in English, but those firms that are of equal size with us, they usually do not."

Language difficulties also increased the need for local presence in Japan because of the needs for local staff that can handle the business negotiations and give after-sales support in Japanese. For instance, one informant from Firm E mentioned that in other countries they have been able to handle their business by using English, but when dealing with Japanese customers, they needed to have employees with very good Japanese skills and cultural knowledge. Firm $\mathrm{C}$ also noted that after the market entry and the establishment of their unit in Japan they have not been able to give support for their unit in Japan in the same scale as for other units because of language problems. For instance, they cannot help with market data collection from the Japanese market because no one in the headquarters has Japanese skills needed.

All case firms also confirmed that the way of doing business in Japan differs greatly from other Western and Asian countries. Differences in business culture were related to working times, the hierarchical management style of Japanese customers and partners, slow decision making process, demanding customers, and time needed for building trustful relationships with customers. For instance, Firms A, B, C, E, and $\mathrm{G}$ disclosed the slow decision making process of Japanese customers and partners that delayed the sales process and the launching of new products in the market. Firms A, $\mathrm{B}$, and $\mathrm{C}$ also highlighted that building trustful relationships with customers was time consuming but needed before the business progressed. Japanese customers were characterized very demanding what comes to products. One informant from Firm E explained the slowness of the decision making and demanding customers in the following way:

"Japanese do not buy anything that is not perfect. When they are 100 percent sure that the product works then they will buy it. For Japanese, it is also important to know who the original developer of the product is and where it is developed."

The hierarchical management style of Japanese customers and partners was also experienced very different compared to other countries. As an example, Firms A, B, and $\mathrm{C}$ had difficulties with finding the right contact persons from the customer's side. Their customers were large multinationals and it was hard to get to know who was responsible for technology purchasing. The management style was also closely related to working times that differed greatly from those that the firms were used to. The manager from Firm F explained the differences of the working times as follows:

"When we are busy in Finland, we still commonly go back home when the working time is over, around four p.m. or at least half past four. However, here the customer trusts that if we are busy, we are still working as long as it takes to get everything done. Going back home earlier...they just do not understand it. They do not understand five weeks' vacations -vacation is not a reason for delays."

The geographical distance and the time difference between Finland and Japan were experienced to hinder the business. This was despite the fact that all the firms were able to deliver their products electronically via Internet. Geographical distance was 
seen as a disadvantage because the Japanese as well as other competitors from geographically nearby countries were able to give support for customers much faster. Appointments and business negations with customers also required lot of traveling and increased costs of doing business. One informant from Firm B expressed this as follows:

"If we have to send employees [to Japan], it easily takes two or three days before they are in our customer's office [in Japan]. Whereas a local competitor can put their whole product development team to a train and they all are there within two hours...it is an obvious advantage for our competitors in Japan."

\subsection{Distance-bridging factors used by case firms}

Despite distance-creating factors discussed above, all the firms were able to use distance-bridging factors to enable their operations in the Japanese market. The distance-bridging factors can be divided into opportunity seeking behavior, recruitment of capable employees, choice of the proper entry mode, networking, and earlier experiences.

All the case firms regarded Japan as a very interesting country for their products already before they started to actively prepare their market entry to Japan. This was mainly related to the large market size and the sophisticated industry structure for the products of the firms. In addition, the domestic markets of the case firms were mentioned to be relatively small and saturated for their niche products. Thus, opportunities motivated managers to enter the Japanese market despite risks and entry barriers. Firms A, C, D, E, and F mentioned that the main reason for the market entry was the large market size and the business opportunities in Japan. In addition, firms $\mathrm{G}$ and $\mathrm{H}$ mentioned the sophisticated industry structure for their products, such as high capacity of broadband and mobile networks. Firm B got an important customer from Japan that motivated to enter the market and search for more business potential there. One informant at Firm A explained their reasons for the market entry as follows:

"The target customers of our product are mobile industry, mobile phone manufacturers, mobile operators, and related electronic industry. This is very strong in Japan. Another thing is that Japan is a very difficult market, if we can succeed there, so we can succeed in other markets as well. Thus, the main reason for the market entry was the huge market potential there."

All the managers in the case firms understood that they do not have the required knowledge to handle business activities in the Japanese market because of significant differences in language, culture, and business practices. For this reason, firms C, D, and $\mathrm{E}$ acquired the relevant knowledge by recruiting international experienced managers who had sensitivity to psychic distance between Finland and Japan to handle their operations in Japan. It was also important that the selected manager was aware of the business environment, culture, language, etc. in both countries, not only what comes to the target country. 
In addition, these firms recruited local employees for marketing and other tasks requiring close cooperation with Japanese customers. Firm F used also this kind of recruitment strategy when they changed their joint venture to a wholly owned subsidiary. Firms A and B were able to handle their customers in Japan by using their current employees as expatriates because of English proficiency of their customers in Japan. Firms $\mathrm{G}$ and $\mathrm{H}$ did not recruit employees for their units because of their different entry mode strategy discussed below.

The selection of the proper entry mode for the Japanese market was also seen as a very important distance-bridging factor. In all the cases, the reason for the direct entry modes in the market was based on the complexity of the firms' products that required close cooperation with the customers and distributors during the sales process. An own unit in the market enabled the after-sales services nearby the customers, the localization and customization work together with customers, and the recruitment of local employees. In addition, the own unit in the market reduced traveling needs between Finland and Japan and facilitated networking with customers and distributors. Although firms $\mathrm{C}, \mathrm{E}$, and $\mathrm{F}$ started their operations by using indirect entry modes, such as exporting and foreign distributors, they very soon established direct entry modes in the market. Firms F, G, and H used cooperative entry modes with Japanese firms, although Firm F changed their entry mode into a wholly owned subsidiary later on. This kind of partnering strategy enabled the usage of local knowledge and the decrease of difficulties related to the Japanese language and culture, remarkably in the market entry phase.

Network relationships had also an important distance-bridging role in the market entry phase and later on in networking with customers and distributors. In the market entry, the firms used formal networks with their current business partners (firms D and $\mathrm{H}$ ), informal networks with friends (firms $\mathrm{B}$ and $\mathrm{G}$ ), and mediated relationships with export promotion organizations (firms A, C, E, and F). The importance of network relationships with the export promotion organizations were highlighted especially among those firms who established wholly owned operations in the market. One of the informants at Firm B highlighted this as the following manner:

"In networking, one good example is Finpro [export promotion organization in Finland], we have used them...they have introduced us to potential customers in Japan. Finpro is good for opening doors to new firms because they have a local authority and a long experience in the field...they know lot of persons."

Firms $\mathrm{G}$ and $\mathrm{H}$ who used cooperative entry modes were able to benefit from networks of their Japanese employees. The manager at Firm G explained the benefit of the joint venture in networking as follows:

"In Japan, it is a substantial benefit that we have local employees. Taking care of the relationships with customers and distributors is much easier. Networking happens through them...In that way, our unit in Japan has a crucial role because they have very good relationships with the actors in the market."

Earlier experiences from other markets also had an important distance-bridging role for all the firms. This was the case although all the firms had a very limited 
knowledge from other markets before they established their operations in Japan. These earlier experiences facilitated mainly in operational level activities such as cost estimations, location and entry mode choice, taxation, business models, etc. However, all the firms announced that such experiences are always very personalized. This was the reason why earlier experiences helped only in operational level activities and not with activities where knowledge of local culture was important.

\subsection{Distance-compressing factors facilitating the market entry of the case firms}

Distance-compressing factors indicated by the case firms were the technologically advanced industry structure, low governmental entry barriers, and the good image of Finland in Japan. The advanced industry structure in Japan facilitated firms' marketing activities, the distribution of products via Internet, and the delivery of product updates. Entry barriers set by the Japanese government were also experienced to be fairly low. Although some of the problems encountered by the firms were related to industry regulations and intellectual property protection, they were actually due to normal practices faced in all the markets. One of the informants at Firm B expressed this as follows:

"Although Japan is a very bureaucratic country...we have not experienced any problems related to legal issues. The problems are more related to business culture and how to do business...maybe it takes a bit more time, paper work and translation."

Firms B, C, D, E, and F disclosed that the good image of Finland acted as a distancecompressing factor. Japanese customers saw Finland as a very advanced country in technology, mainly because of the mobile phone manufacturer Nokia and Linux operating system that are both Finnish. Although none of these firms could estimate how much it actually influenced their business, it was mentioned to be like an "extra" benefit. One manager at Firm D explained this as follows:

"We profiled as a Finnish firm very clearly, because I and my colleague who was also establishing this firm [the subsidiary in Japan] were from Finland...In Japan, Finland has a very good reputation. It was like an extra benefit for our customers that we were from the same country as Linux."

\section{Discussion of research results}

As the case findings reveal, the main distance-creating factors in the market entry were language, business culture, and geographic distance. These findings indicate that when software firms enter a distant foreign market, psychic and geographical distance impact on the market entry of these firms. Thus, although these firms do not tend to follow a step-wise internationalization process from nearby to distance countries [6], [42], [9], [22], [23], psychic and geographical distance are still important factors inhibiting the foreign market entry. 
The actions taken by the case firms to decrease the impact of distance-creating factors were opportunity seeking behavior, recruitment of capable employees, choice of the proper entry mode, networking, and earlier experiences. The findings here reveal that all the distance-bridging factors are not directly related to the psychic distance [2] or environmental differences between the home and the host countries [10]. For instance, the opportunity seeking behavior has very little to do with psychic distance or environmental differences because it is more related to the entrepreneurial behavior of managers. Thus, distance-bridging factors are not solely those that improve the information flow (as opposite for the definition for psychic distance by Johanson and Wiedersheim-Paul [2]). The findings related to distance-bridging factors found here were mainly inline with earlier studies. These studies have revealed that managers' opportunity seeking behavior, [20], [21], [22], earlier experiences [20], [21], [23], recruitment of knowledgeable employees [24], and network relationships [25], [24]. These factors facilitate and accelerate the foreign market entry of software SMEs. However, none of these factors alone helped to overcome distance-creating factors in the foreign market entry. Thus, these factors should be studied as a sum of actions taken by a firm or an entrepreneur to overcome distance-creating factors.

Distance-compressing factors, referring to the macroeconomic conditions which are not under a control of an individual firm or an entrepreneur were the technologically advanced industry structure in Japan, low governmental entry barriers, and the good image of Finland in Japan. Thus, as distinct from distancebridging factors, there were also factors which were not under the control of a firm or an entrepreneur but those facilitated the market entry and decreased the impact of distance-creating factors. For instance, it is very difficult for an individual firm to change these factors, like image of the home country, although it is very important for a firm's survival in the target country (see [43], for further review). The findings in this category also revealed the fact that macroeconomic changes and trade agreements such as GATT and WTO had an impact on the market entry and reduced or eliminated government based entry barriers in Japan. In earlier studies, the Japanese market has been reported to be difficult to enter (see for e.g. [44]), mainly due to the entry barriers set by the Japanese government.

\section{Conclusions}

This paper contributes to the literature by recognizing the impact of distance-creating factors in the foreign market entry of software SMEs. In addition, it recognizes how distance bridging and compressing factors moderate and facilitate the distant foreign market entry. Although earlier studies have focused on some of these factors, such as opportunity seeking behavior or network relationships, this study gives a wider perspective covering all the distance-bridging and distance-compressing factors used by the case firms to facilitate their distant foreign market entry. These all are very important concerns for managerial practice as software firms are increasingly investing and operating on distant foreign markets. For the theory development in the field of international entrepreneurship, the findings here indicate that although psychic and geographical distance have only a minor impact on the general pattern of 
internationalization, the role of these factors have to be considered when a firm enters a distant foreign market. In addition, this paper further develops the analytical framework of Child et al. [10]. The original framework by Child et al. [10] is developed by using large multinationals from Hong-Kong. Findings here reveal that the framework can be also used to analyze the foreign market entry of software SMEs. In addition, this study gives more detailed definitions of the three components (distance-creating, distance-bridging, and distance-compressing) used in the framework.

\section{References}

1. Beckerman, W.: Distance and the Pattern of Intra-European Trade. The Review of Economics and Statistics. 38, 31-40 (1956)

2. Johanson, J., Wiedersheim-Paul, F.: The internationalization of the firm: four Swedish cases. Journal of Management Studies. 12/3, 305-322 (1975)

3. Johanson, J., Vahlne, J-E.: The internationalization process of the firm: a model of knowledge development and increasing foreign market commitments. Journal of International Business Studies. 8/1, 23-32 (1977)

4. Dow, D., Karunaratna, A.: Developing a multidimensional instrument to measure psychic distance stimuli. Journal of International Business Studies. 37/5, 1-25 (2006)

5. Srivastava, R.K., Green, R.T.: Determinants of Bilateral Trade Flows. Journal of Business. 59/4, 623-640 (1986)

6. Bell, J.: The Internationalization of Small Computer Software Firms: A Further Challenge to "Stage" Theories. European Journal of Marketing. 29/8, 60-75 (1995)

7. Coviello, N., Munro, H.: Network Relationships and the Internationalisation Process of Small Software Firms. International Business Review. 6/4, 361-386 (1997)

8. Moen, O., Gavlen, M., Endresen, I.: Internationalization of small, computer software firms: Entry forms and market selection. European Journal of Marketing. 38/9-10, 12361251 (2004)

9. Madsen, T.K., Servais, P.: The Internationalization of Born Globals: an Evolutionary Process? International Business Review. 6/6, 561-583 (1997)

10. Child, J., Ng, S.H., Wong, C.: Psychic distance and internationalization: Evidence from Hong Kong firms. International Studies of Management and Organizations. 32 /1, 36-56 (2002)

11. Nordström, K.A., Vahlne, J-E.: Is the Globe Shrinking? Psychic Distance and the Establishment of Swedish Sales Subsidiaries during the Last 100 Years. In Landeck, M. (ed.) International Trade: Regional and Global Issues. New York: St. Martin's Press, 41$56(1994)$

12. Sousa, C.M.P., Bradley, F.: Cultural Distance and Psychic Distance: Two Peas in a Pod? Journal of International Marketing. 14/1, $49-70$ (2006)

13. Hofstede, G.: Culture's Consequences, Second edition. New York: Sage (2001)

14. Kogut, B, Singh, H.: The effect of national culture on the choice of entry mode. Journal of International Business Studies. 19/3, 411-432 (1988)

15. Tihanyi, L., Griffith, D.A., Russell, C.J.: The effect of cultural distance on entry mode choice, international diversification, and MNE performance: a meta-analysis. Journal of International Business Studies. 36/3, 270-283 (2005)

16. Leamer, E.E., Storper, M.: The Economic Geography of the Internet Age. Journal of International Business Studies. 32/4, 641-665 (2001)

17. Ojala, A., Tyrväinen, P.: Market Entry and Priority of Small and Medium-Sized Enterprises in the Software Industry: An Empirical Analysis of Cultural Distance, 
Geographical Distance, and Market Size. Journal of International Marketing. 15/3, 123149 (2007)

18. Ojala, A., Tyrväinen, P.: Market entry decisions of US small and medium-sized software firms, Management Decision. 46/2, 187-200 (2008)

19. Ellis, P.D.: Does psychic distance moderate the market size-entry sequence relationship? Journal of International Business Studies. 39/3, 351-369 (2008)

20. Freeman, S., Cavusgil, S.T.: Toward a Typology of Commitment States Among Managers of Born-Global Firms: A Study of Accelerated Internationalization. Journal of International Marketing. 15/4, 1-40 (2007)

21. Nummela, N., Saarenketo, S., Puumalainen, K.: A Global Mindset: A Prerequisite for Successful Internationalization? Canadian Journal of Administrative Sciences. 21/1, 5164 (2004)

22. Oviatt, B.M., McDougall, P.P.: Toward a theory of international new ventures. Journal of International Business Studies. 25/1, 45-64 (1994)

23. Oviatt, B.M., McDougall, P.P.: Global start-ups: Entrepreneurs on a worldwide stage. Academy of Management Executive. 9/2, 30-43 (1995)

24. Coviello, N., Martin, K.A-M.: Internationalization of Service SMEs: An Integrated Perspective from the Engineering Consulting Sector. Journal of International Marketing. 7/4, 42-66 (1999)

25. Coviello, N.: The network dynamics of international new ventures. Journal of International Business Studies. 37/5, 713-731 (2006)

26. Freeman, S., Edwards, R., Schroder, B.: How Smaller Born-Global Firms Use Networks and Alliances to Overcome Constraints to Rapid Internationalization. Journal of International Marketing. 14/3, 33-63 (2006)

27. Alden, D.L., Steenkamp, J-B.E.M., Batra, R.: Brand Positioning Through Advertising in Asia, North America, and Europe: The role of Global Consumer Culture. Journal of Marketing. 63/1, 75-87 (1999)

28. Hannerz, U.: Cosmopolitans and locals in world culture. In Featherstone, M. (ed.) Global Culture: Nationalism, Globalization and Modernity, pp. 237-251. CA: Sage (1990)

29. Pett, T.L., Wolff, J.A.: Firm Characteristics and Managerial Perceptions of NAFTA: An Assessment of Export Implications for U.S. SMEs. Journal of Small Business Management. 41/2, 117-132 (2003)

30. Yamin, M., Sinkovics, R., Hadjielias, E.: EU Harmonization, Managerial Perceptions and SME Export Behavior. Journal of Euromarketing. 17/1, 7-21 (2007)

31. Yin, R.K.: Case Study Research: Design and Methods. California: Sage Publications. (1994)

32. Eisenhardt, K.M.: Building Theories from Case Study Research. Academy of Management Review. 14/4, 532-550 (1989)

33. Shenkar, O.: Cultural Distance Revisited: Towards a More Rigorous Conceptualization and Measurement of Cultural Differences. Journal of International Business Studies. 32/3, 519-535 (2001)

34. OECD: Officially-supported export credits and small exporters, Organization for Economic Co-operation and Development, Paris, France. (2003)

35. Spence, M.: International Strategy Formation in Small Canadian High-Technology Companies: A Case Study Approach. Journal of International Entrepreneurship. 1/3, 277 $296(2003)$

36. O'Farrell, P.N., Wood, P.A., Zheng, J.: Internationalisation by Business Service SMEs: An Inter-Industry Analysis. International Small Business Journal. 16/2, 13-33 (1997)

37. Huber, G.P., Power, D.J. Retrospective Reports of Strategic-level Managers: Guidelines for Increasing their Accuracy. Strategic Management Journal. 6, 171-180 (1985) 
38. Miller, C.C., Cardinal, L.B., Glick, W.H.: Retrospective reports in organizational research: A reexamination of recent evidence. Academy of Management Journal. 40/1, 189-204 (1997)

39. Bonoma, T.V.: Case Research in Marketing: Opportunities, Problems, and a Process. Journal of Marketing Research. 22/2, 199-208 (1985)

40. Miles, M.B., Huberman, M.: Qualitative Data Analysis: An Expanded Sourcebook. California: Sage Publications. (1994)

41. Pettigrew, A.M.: Longitudinal field research on change: Theory and practice. Organization Science. 1/3, 267-292 (1990)

42. Crick, D., Jones, M.V.; Small High-Technology Firms and International HighTechnology Markets. Journal of International Marketing. 8/2, 63-85 (2000)

43. Roth, K.P., Diamantopoulos, A.: Advancing the country image construct. Journal of Business Research. 62/3, 277-284 (2009)

44. Mason, M.: United States Direct Investment in Japan: Trends and Prospects. California Management Review. 35/1, 98-115 (1992) 